\title{
Notes on the vocalizations of Grey-brown White-eye (Zosterops cinereus)
}

\section{Peter Boesman}

In the following we briefly analyze and compare voice of the two races of Grey-brown White-eye (Zosterops cinereus). We also try to quantify the extent of any vocal differences using the criteria proposed by Tobias et al. (2010), as a support for taxonomic review.

We have made use of sound recordings available on-line from Xeno Canto (XC) and Macaulay Library (ML), where Douglas Pratt has deposited a nice collection of recordings of both races.

Voice of both races is quite different:

\section{ponapensis}

song: alternating fairly melodious high-pitched whistles, slurs and burry notes uttered at a leisurely pace, without any regular pattern

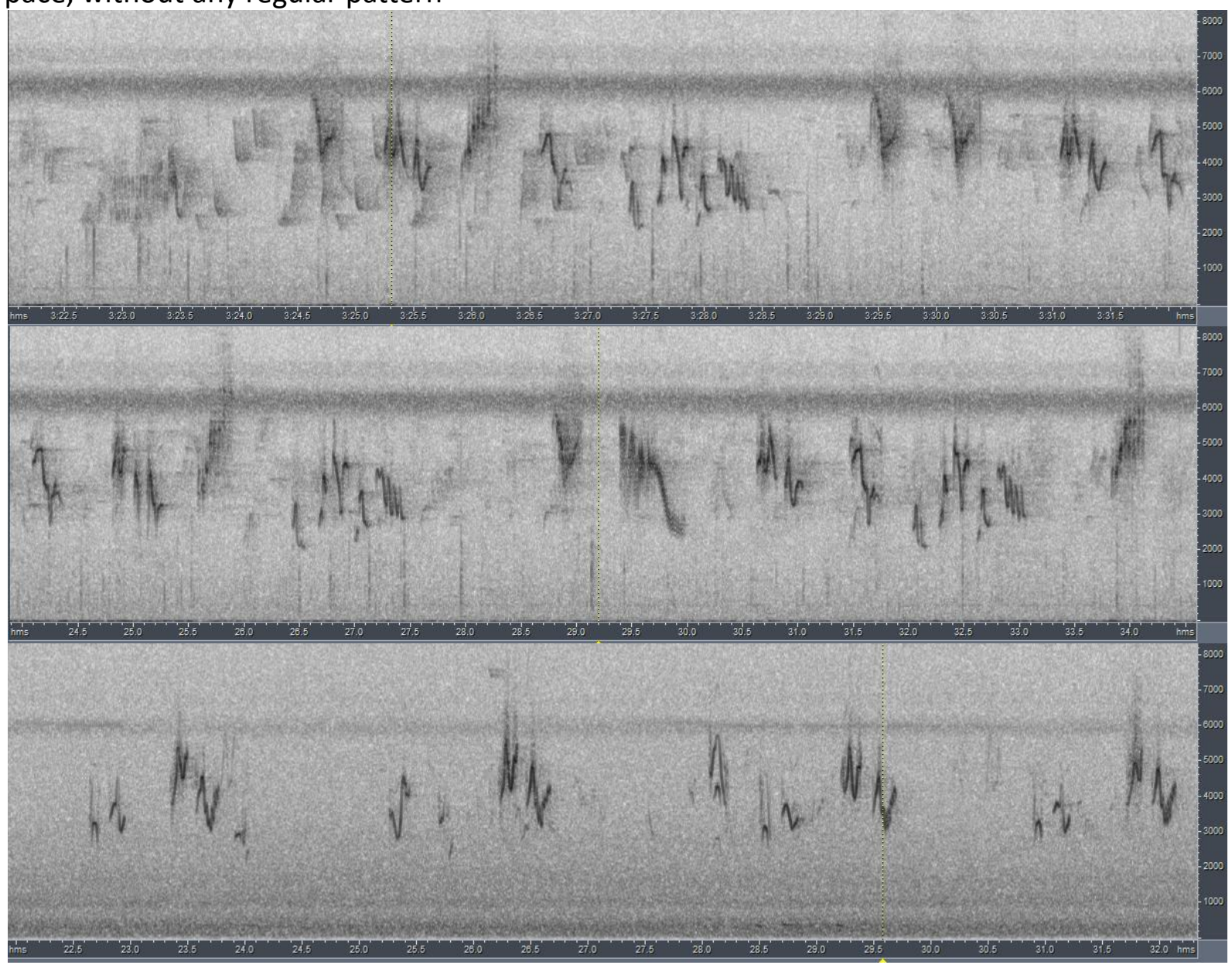




\section{HANDBOOK OF THE \\ BIRDSPITTEE WORLD Alue}

\section{ORNITHOLOGICAL NOTES}

\section{calls}

short, hoarse notes:

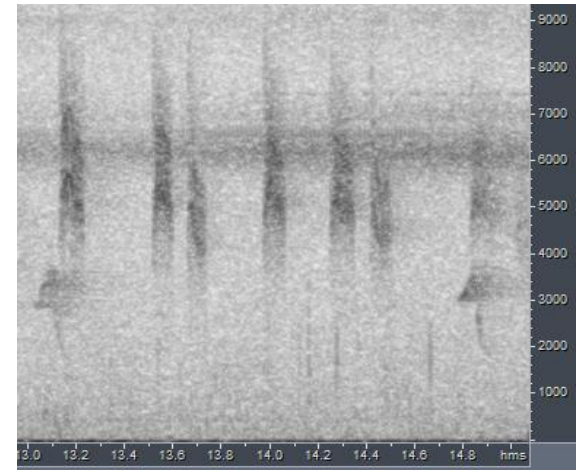

sometimes lower-pitched and more nasal:

short downslurred melodious note
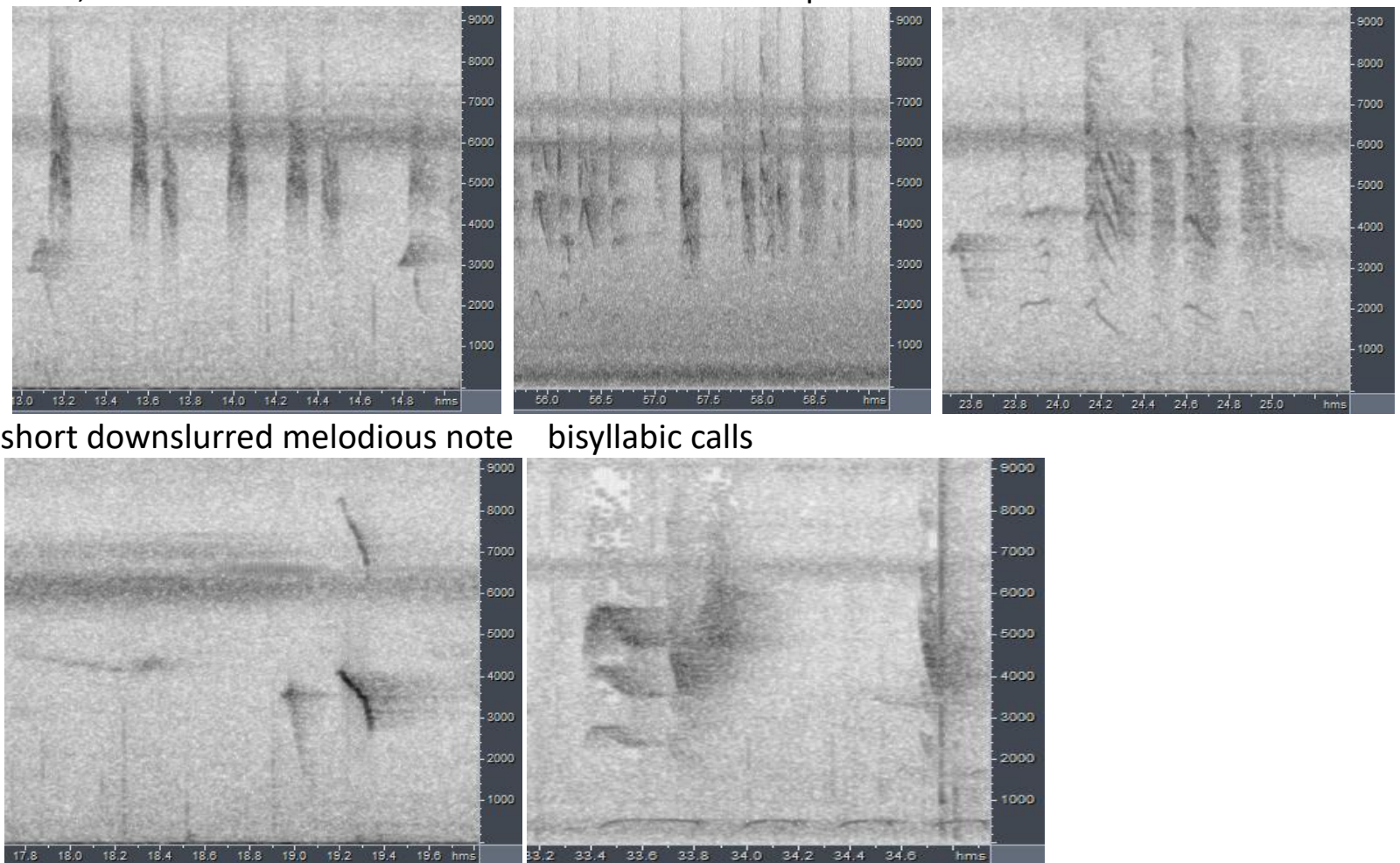

bisyllabic calls

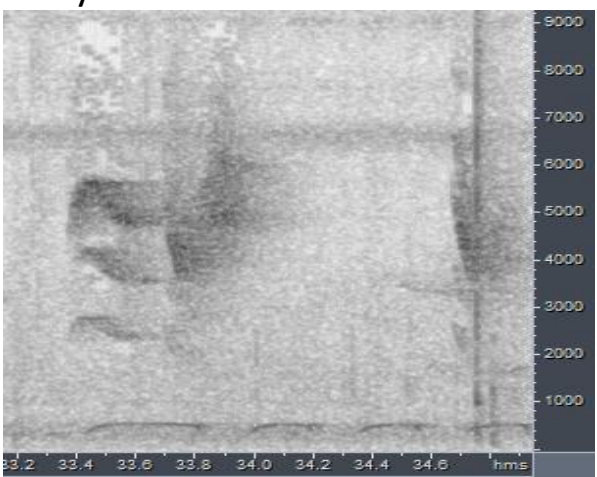

\section{cinereus}

song: apparently not recorded or else simply a sequence of several different chirp-like notes

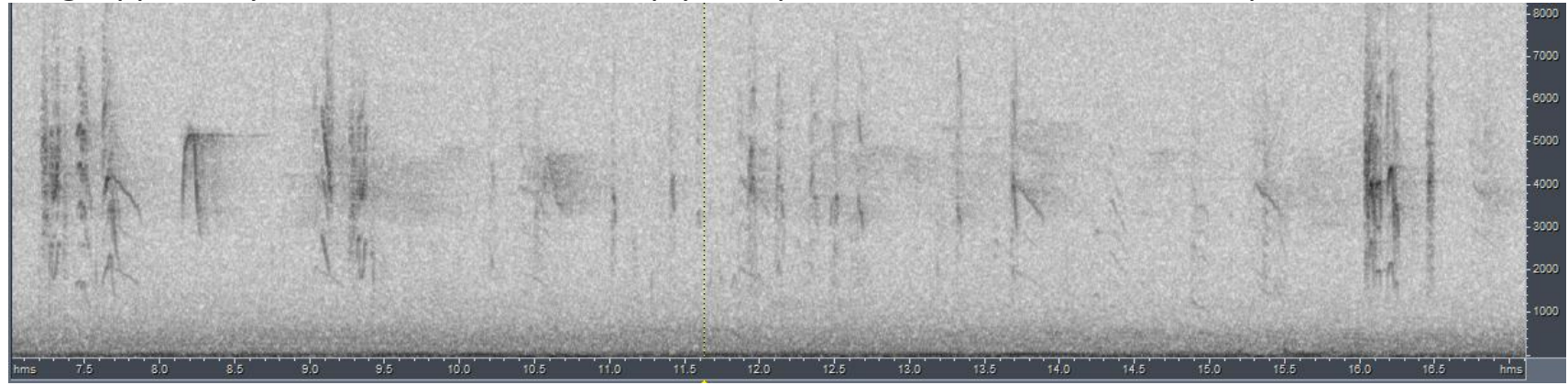

calls

Very House Sparrow-like chirps (unlike the hissing/hoarse notes of ponopensis)
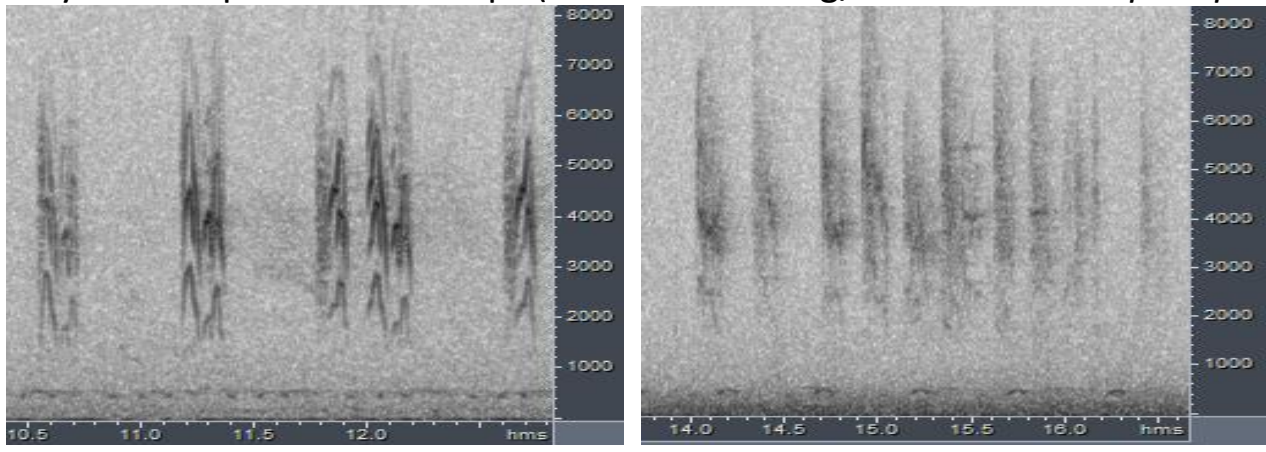

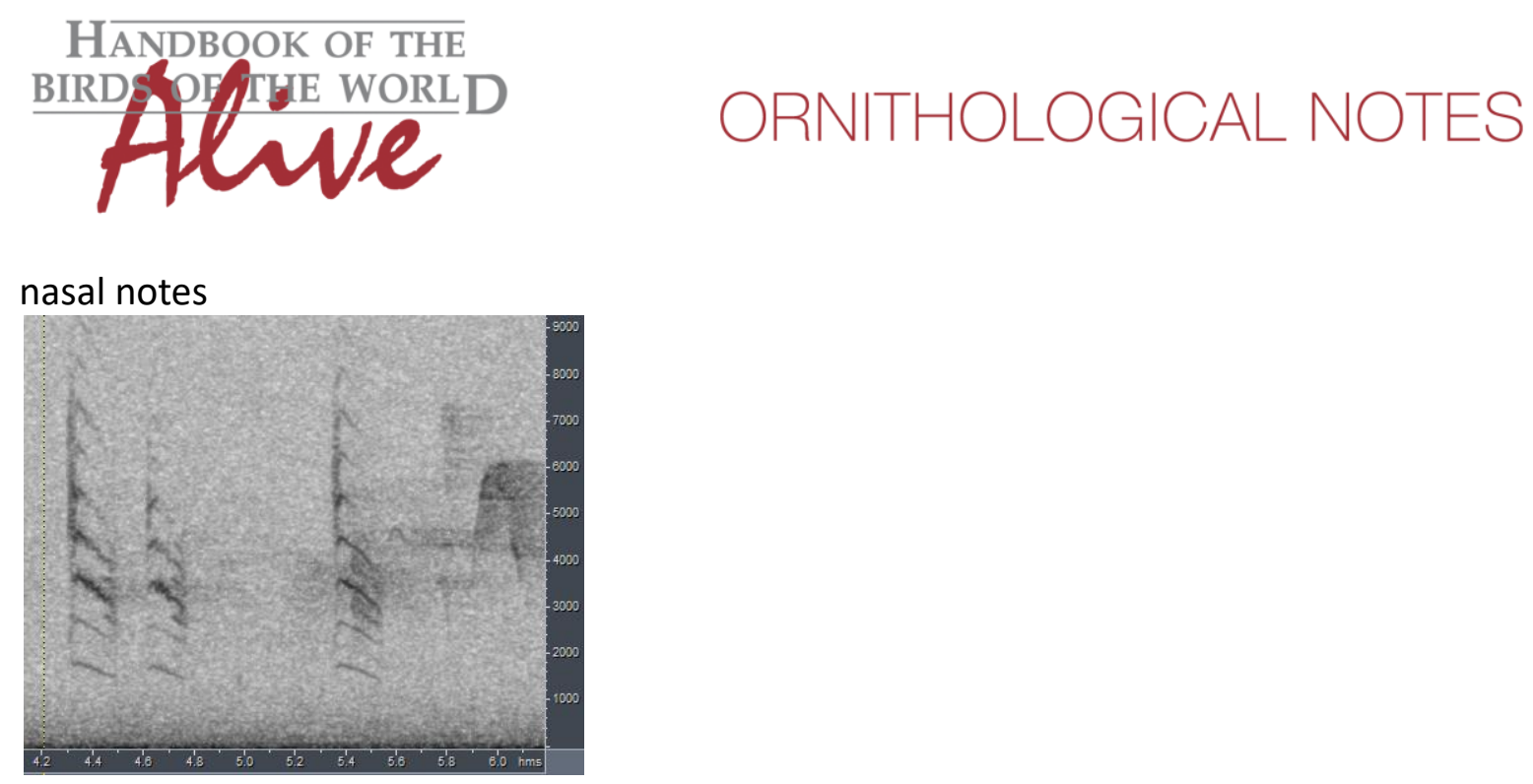

While it is possible that cinereus has a song which has not been recorded yet (despite the 20+ recordings mainly taken early in the morning), it seems more likely that the song is a continuous series of variable chip-like notes. In this case, song obviously very different from ponapensis (which would lead to a vocal score of about 4 based on pitch, note length, note shape etc.) Call notes are also very different. The commonest call of cinereus being rather loud very HouseSparrow-like chirps, and in the case of ponapensis higher-pitched somewhat hoarse/hissing notes (score 3-4 based on pitch, note shape etc. if we consider these vocalizations to be homologous). Other call notes which are uttered less frequently seemingly also quite different.

All in all, it would seem that vocabulary of both races is quite different. An estimated total vocal score of about 4 seems appropriate given there is still some doubt about song.

This note was finalized on 7th April 2016, using sound recordings available on-line at that moment. We would like to thank in particular the sound recordists who placed their recordings for this species on XC and ML: Douglas Pratt and Mark Todd.

\section{References}

Tobias, J.A., Seddon, N., Spottiswoode, C.N., Pilgrim, J.D., Fishpool, L.D.C. \& Collar, N.J. (2010). Quantitative criteria for species delimitation. Ibis 152(4): 724-746.

\section{Recommended citation}

Boesman, P. (2016). Notes on the vocalizations of Grey-brown White-eye (Zosterops cinereus). HBW Alive Ornithological Note 264. In: Handbook of the Birds of the World Alive. Lynx Edicions, Barcelona. (retrieved from http://www.hbw.com/node/1251703 on 5 October 2016). 